\title{
The "Bollywoodization" of Popular Indian Visual Culture: A Critical Perspective
}

\author{
Keval J. Kumar \\ Adjunct Professor, Mudra Institute of Communications, Ahmedabad, India. kevalku- \\ mar@hotmail.com
}

\begin{abstract}
The roots of popular visual culture of contemporary India can be traced to the mythological films produced by D. G. Phalke during the decades of the 'silent' era from 1912 to 1934 . The era of the "talkies" of the 1930s ushered in the "singing"' or musical genre, which together with Phalke's visual style remains the hallmark of Bollywood cinema. The history of Indian cinema is replete with films made in other genres and styles (e. g., social realism, satires, comedies, fantasy, horror, or stunt) in the numerous languages of the country. However, it is the popular Hindi cinema (now generally termed Bollywood) that has dominated national Indian cinema and its audiovisual culture. It has hegemonized the entire film industry as well as other popular technology-based art forms including the press, radio, television, music, advertising, the worldwide web, the social media, and telecommunications media. The form and substance of these modern art forms, while adapting to the demands of the new media technologies, continued to be rooted in the visual arts and practices of folk and classical traditions of earlier times.
\end{abstract}

Keywords: Visual Culture, Hegemony, Visual Style, Indian Cinema, Indian Television, Indian Advertising

\section{Introduction}

Infinite diversity, plurality and multiplicity are the primary features that mark popular Indian visual culture. This culture has come about through centuries of absorption, integration and acculturation, as the subcontinent evolved at its own leisurely pace engaging with invaders, settlers and colonialists who brought with them audio and visual cultures of their own. Conversations and exchanges with these different cultures over two millennia gave rise to the ecumenical, syncretic and hybrid cultures of contemporary India.

There were along the way many conflicts and resistances, narrow chauvinisms, nativism, even fundamentalism. These tendencies also contributed to and in some ways vitiated attempts at fusing the many strands that make for any national visual culture. The fine and the plastic arts, the applied arts, the performing arts, literature, and the numerous local and regional folk art traditions contributed to this evolution. True, some cultures dominated in each space. Others fell by the wayside, most just plodded along, happy to be left alone. The Greeks, the Jews, the Armenians, the Persians, the Syrians, Sakas, Hunas, Turks and Mongols, and finally the Europeans (mainly French, Portuguese and British) came, as explorers, traders, missionaries, and invaders: some left in a hurry, others stayed on for some time, while still others settled down among the natives and made the country their home. The colonizers from Central and West Asia stayed for more than three centuries (1526-1857), though many came, plundered and went away, the Europeans remained for almost a hundred years (1858-1947); while the Mughals stayed on and ruled some parts of North, West and South India, the Europeans edged out the Mughals, except some princely kingdoms, and then transformed much of the subcontinent into the British Raj. All and sundry cultural groups left their mark and even blended into the huge melting pot of native Aryan, Dravidian, and tribal cultures. In their turn, Indians travelled to other parts of the world, including the countries that colonized India, giving rise to 'old' and 'new' diasporas of over 24 million in around a hundred countries, though largely concentrated in North America, Great Britain, South Africa, Fiji, Australia, West Asia and parts of South-East Asia. 
This paper presents a historical account of how Bollywood cinema's visual style has influenced not just filmmaking but most other popular art forms in the different regions, cultures and languages of India. The attempt is to trace the historical roots of this hegemonic visual style and how it has stunted the growth of other styles prevalent in India's varied cultures. The focus will be on popular media such as cinema, television, music, and social and religious celebrations such as weddings and festivals. This evaluation of Bollywood and its hegemony as well as resistances to it will be analyzed from critical political economy and cultural studies perspectives.

\section{The Roots of Indian Visual Culture}

Popular Indian visual culture has its roots in nature and the spiritual as embodied, for instance, in the cave paintings at Ajanta, the sculptures in Ellora and Khajuraho, and in the mix of architectural styles of hundreds of temples, mosques and churches and other types of shrines and pilgrim centers around the country. Further, the many forms of dance, theatre and music, both in classical and folk traditions, have contributed to the efflorescence of national, regional and local visual cultures.

In this visual culture, there has always been a search for "the sense of the beautiful" ('ramaniya' in Sanskrit), which, according to Dasgupta $(1960,1)$, results from a devotee's meditation (or 'dhyan') and finds expression in "rasa" (delight, pleasure). For Indian aesthetes like Jagannatha of the $17^{\text {th }}$ century, the "beautiful" was that which induced a unique feeling of pleasure, "an emotional thrill", "a particular type of harmony" (Dasgupta 1960, 2). The Indian ideal of pictorial representation differs widely from that of the Greeks. Dasgupta contrasts the two styles as follows:

With the Greeks, man was super-important and nature played an insignificant part, and was therefore neglected. In India, however, man is regarded as a part of nature and the representation of man or of gods was indispensably associated with the representation of such lovely forms of nature as could be in harmony with it. On the one hand, faithfulness to nature and natural forms was attended to, and on the other hand, it was transcended by the inner intuitive vision, throbbing with the emotive personality of the artist. (Dasgupta 1960, 20)

Thus, the object of the artist in representing gods and goddesses was not to imitate the excellence or beauty of human forms, as was the case with the Greeks, but to give expression to a spiritual message that the forms of gods were intended to impart (ibid., 15). This explains why there is a prevalence of images of deities, which, though appearing to be "mostly human figures", are yet divine. For example, Durga has ten hands, Siva and Brahma have five faces, and Ganesh has an elephant's face and trunk. This approach to representations in art shaped the evolution of popular visual culture in the technological media such as the press, photography, cinema, television, recorded music, and later in the digital media, such as video, social media and telecommunication media.

\section{Visual Culture Prior to Cinema}

Much before the arrival of the cinema in India, shadow puppetry and the folk tradition of pat painting demonstrated that the illusion of moving images could be created. In pat (or scroll) painting, for instance, pictures are painted in a series on a long scroll, and the chitrakathi or painter-cum-narrator, recited (a story) alongside (Chabria 1994, 3). Their repertoire consisted of illustrations of proverbs, folk tales and mythology. A variation of this was the pabujaki par (religious scroll paintings) of Rajasthan, in which the entire narrative of a traditional heroic saga is painted on a large screen. During the nocturnal it is lit in segments and the stories are narrated for several hours over a period of days (Chabria 1994, 3).

When photography came to India in 1840, a year after its introduction in the West, Indian photographers used it for making portraits and "documentary" style views (Chabria 1994, 3). In both forms, the photographers drew from native visual conventions. Thus, portraits were 
directly painted on the photographs, and a similar planar flatness emphasizing frontality was also incorporated into the view. These practices were distinct from the Western preference for depth, perspective and symmetry (Chabria 1994, 3). Then there were Indian versions of magic lanterns around the same period, which were used to tell stories from Indian epics.

\section{Early Indian Cinema}

In May 2013, India celebrated the $100^{\text {th }}$ anniversary of the first Indian feature film, Raja Harishchandra by D. G. Phalke. The beginnings of Indian cinema can be traced to July 1896, barely six months after the Lumière brothers exhibited their "actualities" in the basement of the Indian salon in Paris. The early attempts were brief shots, documentaries of street scenes, wrestling matches and festivals. Phalke's feature was a "mythological" one, a wellknown story of a Hindu king who, like Job of the Old Testament, was tested for his fidelity to God by being stripped of his worldly possessions. The inspiration for making a film based on Hindu mythology came from Phalke's viewing of a British feature film entitled Life of Christ. However, he wanted to make an "Indian" film, telling a Hindu story in an Indian narrative style. So his narrative form, décor, costumes, mise-en-scène, representations of the male and female bodies, the acting style, and in general the "look" of the film was inspired by traditions in Indian folk drama, the Parsi proscenium theatre, contemporary architectural and painting styles, and printing methods like lithography and chromolithography. (Figure 1 offers an instance of that 'look'.) A major influence was, however, Raja Ravi Varma, an artist and printer who adapted British academic painting of the time, and in the process anglicized Indian gods and goddesses, giving them idealized human forms. His mass reproductions of these paintings became part of the established visual culture and popular iconography (Dasgupta 1991, 21). Further, the "iconic frontality" in the work of Varma and Phalke is not of Indian origin. Rather, it follows a European tradition in which the subject looks directly at the beholder. By contrast, in the tradition of Indian art, Hindu gods face the devotee, ready to receive his prayer, but they do not look directly at him (Dasgupta 1991, 22). Indeed, it is the devotee who looks up to the gods and takes their darshan (Sanskrit, "blessed vision", "divine gaze").

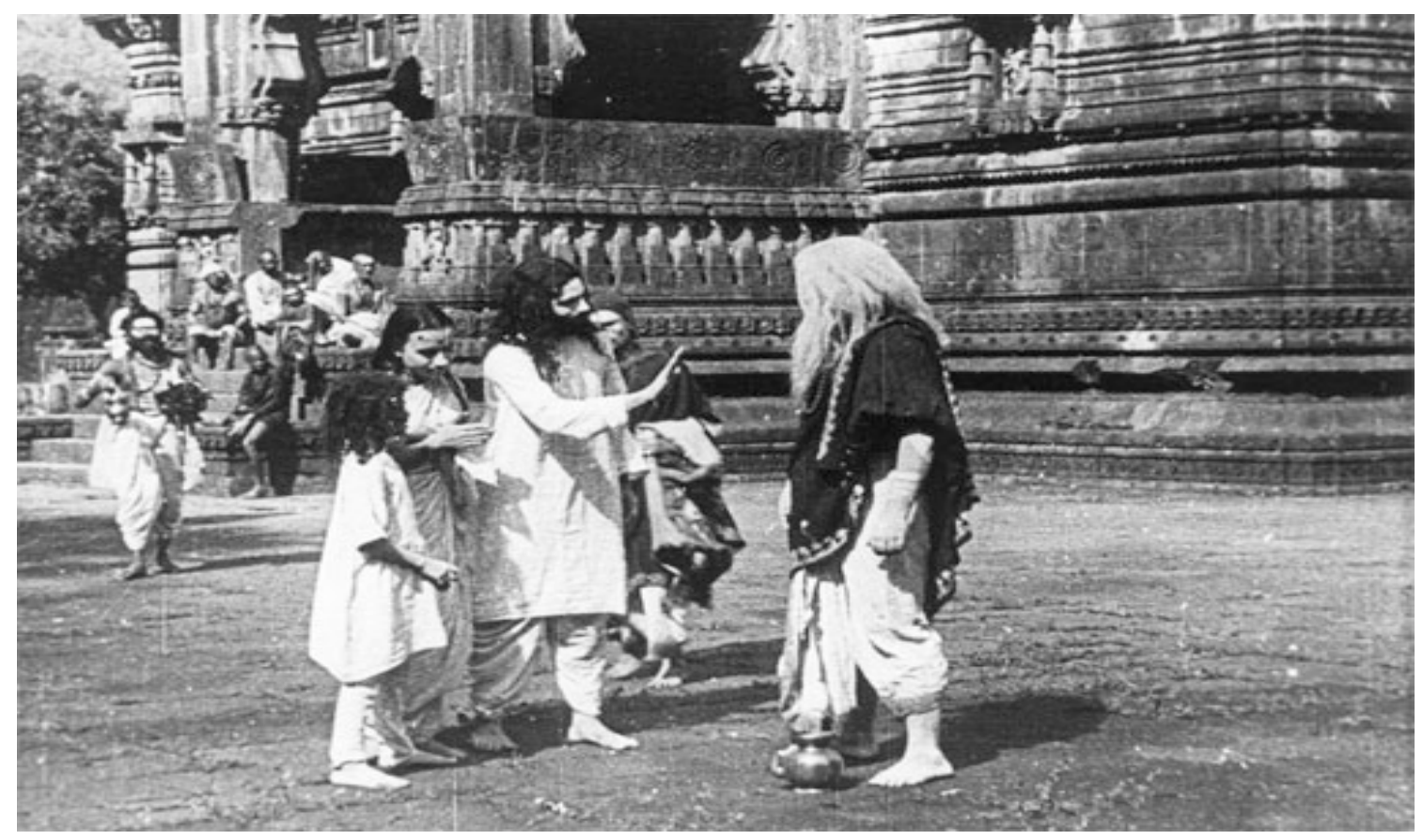

Figure 1: A scene from Phalke's Raja Harishchandra. ${ }^{1}$

\footnotetext{
${ }^{1}$ Source: A_scene_from_film,_Raja_Harishchandra,_1913.jpg. Accessed January, 19, 2014.
} 
For some anthropologists and film scholars (e. g. Babb 1981, Eck 1998, Prasad 1998, Rajadhyaksha 2004) the concept of "darshan" is central to popular Indian/Hindu visual culture; it is used primarily in religious contexts though also in some secular contexts. It points to the relationship between the visual object and the viewer/spectator. So, audiences of early Indian cinema went to the theatre to seek darshan of the gods and goddesses represented on the big screen. In later years, as film "stars" turned into national and regional icons, audiences took their darshan, too. Political leaders, social reformers and even figures and teachers rose in esteem of the Indian public; their darshan was eagerly sought for. The uniqueness of this "Hindu way of seeing" is contested by Vidal (2006).

This visual style of "iconic frontality" dominated Phalke's mythological films such as Raja Harishchandra (1913), Lanka Dahan (1917) and Krishna Janma (1918), and indeed his entire oeuvre. The form and substance of Phalke's pioneering feature was to influence film making in the sub-continent for decades to come. Later, "singing" and "talking" films led to the dramatic flowering of cinema in the many diverse languages and regions of India.

\section{The Many Meanings of "Bollywood"}

The term "Bollywood" owes its origins to film critics and columnists of the city of Bombay of the 1970 s and 1980s. First it was used casually, though sometimes disdainfully, to dismiss the all-India Hindi film. However, by the late 1990s, it became "regular usage" in the trade papers of the time (Vasudevan 2011, 8).). Clearly, it may have been used at various times, but not so systematically as now (ibid., 2011, 7). Vasudevan believes the term "emerged in the wake of the success of the diaspora-themed films from Dilwale Dulhaniya Le Jayenge ('The Brave Heart Will Take the Bride') (1995) onwards", though more specifically "the term might have been associated with the reinvention of the family film genre to address not only diaspora audiences but to provide a mise-en-scène for the new type of commoditization that had developed around cinema in India" (Vasudevan 2011, 8).

The portmanteau word "Bollywood" has several connotations. Rajadhyaksha (2004), for instance, speaks of the "Bollywoodization" of Indian cinema, and Thussu (2009), in his discussion of News as Infotainment spells out what he calls the Bollywoodization of television news in India. However, few film scholars set out very clearly what the various elements of this phenomenon are.

There is a consensus, though, that Bollywood is best exemplified by the blockbuster Hindi films of the mid-1990s, released immediately after the "liberalization" or opening up of the Indian economy to foreign investments, and more importantly, of the national government's declaration that cinema is an "industry" and is therefore entitled to assistance from financial institutions like banks and insurance companies and to approach the stock markets for public participation as shareholders. Films targeted at the affluent overseas Indian proliferated during the first decade of the new millennium; so did academic research, largely by Indians of the diaspora, on this new type of audiovisual culture.

A whole new field of Bollywood Studies (Thussu 2013) has begun to flourish, particularly in the United States and the United Kingdom. Today, it hegemonizes and sets the agenda of Indian Film Studies. To Thussu (2013), this "field" has "remained predominantly critical, theoretical and historical in focus," but what the author overlooks is that it is pretty narrow in scope, restricted as it is to Bollywood, the "export-oriented transmedia product" (Dwyer \& Pinto 2011: xiv) with its focus on the North-Indian Hindu family, its traditions and its values. For Rajadhyaksha (2004), Bollywood is not just a product but an "ensemble of interests that govern the contemporary entertainment industry, where film is only one element, even if from which other entertainment and consumer sectors -television, music, advertising, fashion and websites - derive cultural capital" (Vasudevan 2011, 8), For Rajadhyaksha, the typical Bollywood film addresses a family audience, though since the late 1990s it has been mainly feeding "the nostalgia industry" (Rajadhyaksha 2004, 137) of the Indian diaspora. He points out that in the 1950s, the Indian State regarded cinema as the repository of national cultural values, and attributed to it a nationalist function, namely, that of national integration. In the 
1990s, the Bharatiya Janata Party (BJP) took to cinema to promote what it called "cultural nationalism", which was nothing but a disguise for the ideology of Hindutva.

For Dudrah (2006), however, Bollywood is "an important catchword in the vocabulary of global South Asian popular culture". For others, Bollywood is at the heart of "Bollystan", a borderless world that connects PIOs (Persons of Indian Origin) outside of India (Uppal 2013). Bollywood Studies had over a dozen theorists in the 1980s and over two dozen by the end of the 1990s (Gehlawat 2010, xi). Over the last decade, many more theorists have made their mark in the "field". These theorists deliberately exclude the myriad other popular cinemas of India in regional languages as well as the "art", "parallel" and "middle" cinemas in all Indian languages including Hindi and its various dialects (cf. Kumar 2010, 2011; Uhl \& Kumar 2004).

\section{Bollywood on Television}

The early years of Indian television were dedicated to public education. The single television channel (which later came to be called Doordarshan) carried no commercials. Most programs were sourced from the United States, Britain and Germany. Indian programs included news bulletins, Hindi films, and film-based shows. Indeed, the most popular programs until the mid-1980s were Bollywood feature films and video-clips from the same films, strung together theme or singer-wise, and labelled Chaya Geet and Chitrageet. The Hindi film industry took over the small screen when one of the foremost film producers of the time, Ramanand Sagar, produced the first Indian devotional soap opera, Ramayana, based on the epic of the same name. It turned out to be a "mythological" one in the Phalke style. Its grandiose settings and costumes, its theatrical acting style and mise-en-scène took viewers back to the early days of Indian cinema. Other soap operas of the time, while following the genre introduced by the Mexican telenovela, had the "look" of the Bollywood family dramas of the 1950s and 1960s. Such too were the "K-Soaps" (named after the most prolific producer of the time, Ekta Kapur) of the 1990s and 2000s. By then, Bollywood stars and directors had a free run of the entertainment channels, offering Reality TV shows, particularly song and dance contests, anchoring game shows and quiz programs, and participating as judges. They also figured prominently on news channels as interviewees, discussants, reviewers and experts. On one occasion, two top stars also presented the news on a national English language channel. The songs and "item numbers" (Brara 2010, 67) of Bollywood films figure regularly on music channels such as MTV and Channel V.

Advertisements on television are replete with Bollywood stars promoting consumer products and services. They dominate testimonial advertising as much as they do public service advertising. The biggest star of them all, Amitabh Bachchan, is the "brand ambassador" of Gujarat Tourism. (See Figure 2 for a still from the advertising campaign to promote tourist sites of Gujarat.) He peddles more than 40 products, from textiles to consumer durables and luxury brands. Other film stars seen more often on television programs and advertisements than on the big screen are Shahrukh Khan, Salman Khan, John Abraham, Priyanka Chopra and Katrina Kaif. The same familiar stars make their appearance regularly in news columns and advertisements in the mainstream print media. Larger-than-life billboards in the metros and in the cityscape of large cities look down on motorists and passers-by, promoting new film releases, educational institutes, real estate agencies, and consumer products. Bollywood is omnipresent, whether in outdoor advertisements or in the privacy of domestic spaces. The new digital media are no exception. Bollywood films are now actively propagated and released on YouTube and on other video-sharing sites, and the songs and music and "item numbers" from films proliferate in cyberspace by the hour. In the telecommunication media, Bollywood content rules the roost in terms of games, video-clips, item numbers, radio, music, ring-tones and call-back tunes. 


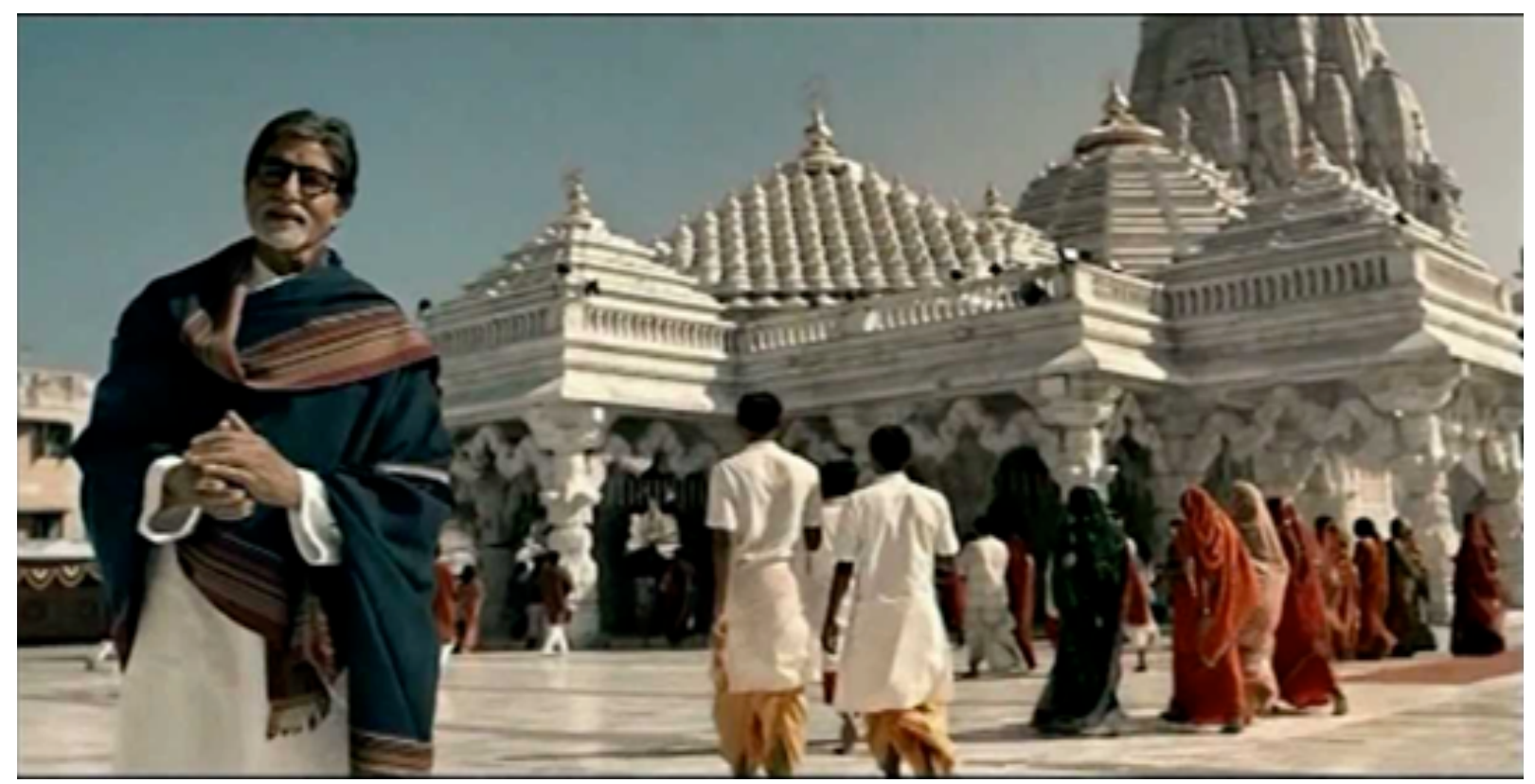

Figure 2: Amitabh Bachchan: "Brand Ambassador" of Gujarat Tourism. ${ }^{2}$

\section{Visual Culture and the Elite Middle Class}

Drawing on interviews with the elite middle class, Fernandes $(2000,614)$ concludes that "visual signs of wealth have come to be the new symbols of national progress in India". Participation in the cosmopolitan fashion industry is one symbol of India's participation in the global economy, for instance, in international beauty contests. She found that $80 \%$ of male and female characters on Indian television belonged to the upper stratum of society (ibid.). It is this same class dominating in film, the tabloid press, and advertising that is calling the shots where popular Indian visual culture is concerned. This class predominates in the media professions as well as in the media representations of the country's visual culture. There is a clear absence of the subaltern and the poor in this new culture.

Wedding celebrations best illustrate such demonstrations of "visual signs of wealth", flaunted by the new consuming middle class. Weddings have been transformed into management events, with wedding planners and designers in great demand. These event managers emerged in early 2000 as "new specialists of lifestyle desires" (Brosius 2010, 274). The inspiration for wedding themes is evident in Bollywood films of the late 1990s, such as Dilwale Dulhania Le Jayenge (1995), Hum Aapke Hai Kaun (1994) and the cross-over film Monsoon Wedding (2001). Posters of Bollywood films play a vital role in propagating romantic looks/themes taken up by wedding planners and fashion designers. (See Figure 3 for one such poster for "the longest running film in the history of Indian cinema".). The most popular wedding themes in terms of cost are: Celebrity (Rs. 6.0 million), Palace Wedding (Rs. $4.5 \mathrm{~m}$ ), Yacht (Rs. 4.5 m), Desert (Rs. 4.0 m), Beach (Rs. 3.5 m), and Bollywood (Rs. $2.5 \mathrm{~m}$ ) (Dutta $2013,11)$. The demand for these theme-inspired weddings has given rise to a flourishing bridal industry, which includes magazines, websites, blogs, fashion, and jewellery. Weddings are seen by the elite middle class "as a stage for the display of "world-class" lifestyle (Brosius 2010). The sociologist Krishna Kumar observes that the Indian urban middle class concern with marriage, working as a source of social prestige, is "almost obsessive" (Brosius 2010, 274).

\footnotetext{
${ }^{2}$ Source: http://i3.ytimg.com/vi/V-JiDBEHryc/0.jpg , accessed January, 19, 2014.
} 


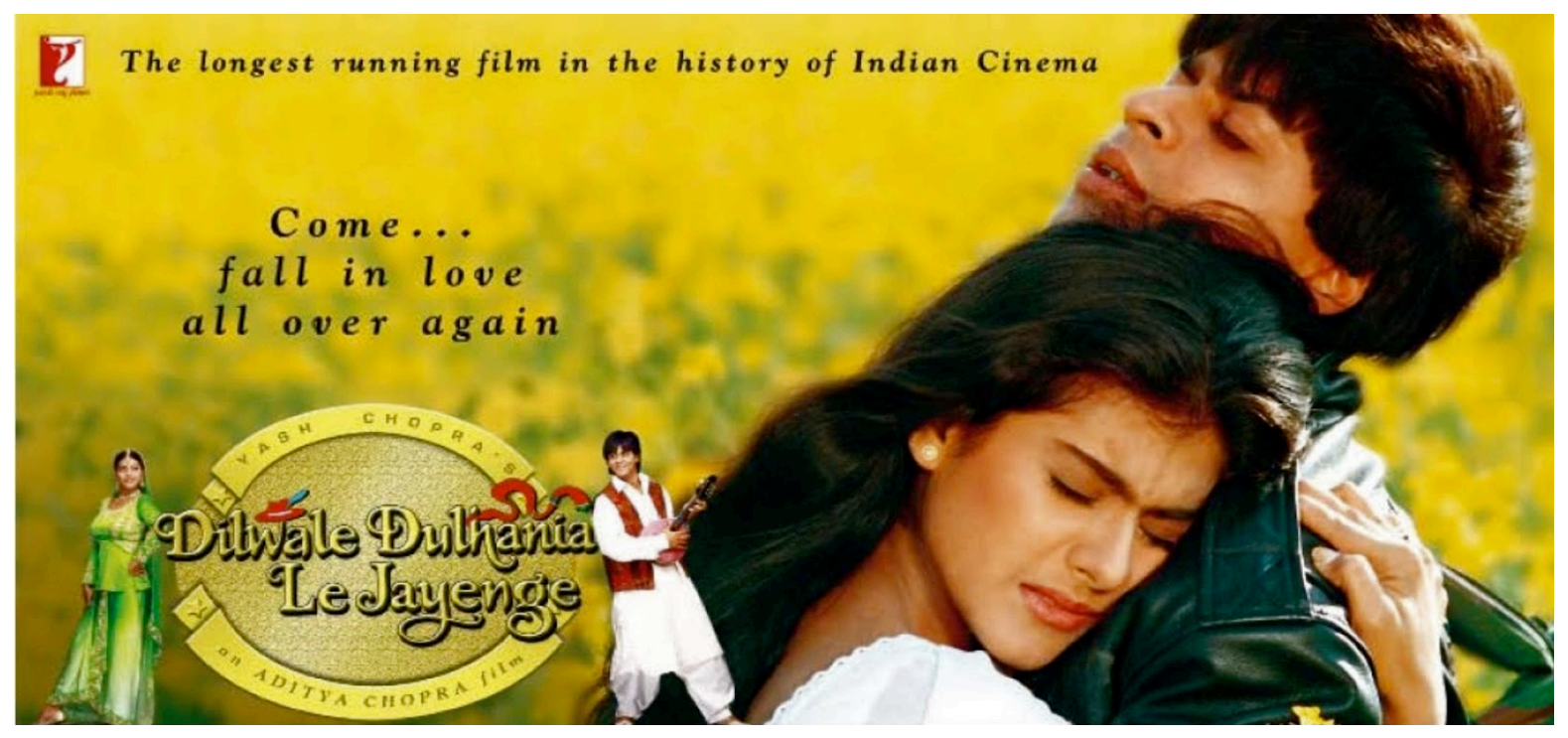

Figure 3: Poster for the Bollywood Film Dilwale Dulhaniya Le Jayenge (The Braveheart Takes the Bride). ${ }^{3}$

\section{Conclusion}

Indian visual culture may have been bollywoodized over the last two decades or so, but this development has not gone unchallenged. The resistance to Bollywood's many attempts to take over has been led by filmmakers and other visual artists from different parts of the country as well as from the diaspora. This counter-hegemonic movement, still in its nascent stages, offers varied and alternative works of art, which celebrate subaltern perspectives. Three recent examples of this new trend are the Punjabi film Gift of a Blind Horse by Gur Gurvinder Singh which takes us to the conflicts and deprivations in rural Punjab in a nonlinear ManiKaul-like style, shattering the myth of the Green Revolution, and two other recent NFDC (National Film Development Corporation) films, The Lunchbox (2013) and The Good Road (2013), which pull no punches in opening our minds to the experience of the working classes.

Already, Bollywood is in a free fall, particularly in what is termed "the overseas market" (Kohli-Khandekar 2013, 11). Revenues from this once-profitable market have declined from $30-40 \%$ to $20-25 \%$ over the last decade (ibid.). The FICCI-KPMG Report (2013) suggests that the global market brings only $6.7 \%$ of total revenue to the Bollywood genre of films. Films that have become box-office successes in North America and Great Britain often do not have many takers on the domestic market. Two recent examples of such films are $M y$ Name is Khan (2010) and Bhaag Milkha Singh (2012). Further, most experimental films, which do well on the domestic market fail to make it to the Indian diaspora. Some recent examples of these are: Omkara (2006), Johnny Gaddar (2007), Kahani (2012), The Dirty Picture (2012), Vicky Donor (2013), and Kai Po Che (2013).

Indeed, the days of the typical Bollywood film are numbered, and the euphoria of the last two decades is on the wane. The future of the elite and urban-centric Bollywood film that is targeted primarily on the diaspora is uncertain. The regional cinema is gaining in strength, with a greater variety of films. American studios (the "majors") are investing heavily in the Indian domestic market; for them the diaspora is not as promising a market as the Indian middle class.

India's visual culture is gradually moving out of the shadows of Bollywood. Independent films (the "indies") have begun to experiment with form and narrative, and they are making inroads into the Bollywood dominated film business. This bodes well for the new visual culture that is emerging in the subcontinent. There are of course some worrying threats, too. Religious and political lobbies that are intolerant of an open and secular society are wont to

\footnotetext{
${ }^{3}$ Source: http://byobollywood.com/wp-content/uploads/2013/07/ddlj.jpg . Accessed January 20, 2014.
} 
use muscle and street power to censor and to control. The late M. F. Hussain, one of India's major contemporary artists, was one such victim; he was forced into exile in Dubai. Historians, cartoonists, novelists, documentary filmmakers and independent thinkers have had to face the wrath of these lobbies. Only time will tell whether the vibrant visual culture of India, known for its diversity and openness, will survive Bollywood and the lurking threats from fascist and fundamentalist forces.

\section{References}

Babb, Lawrence. 1981. A Glancing: Visual Interaction in Hinduism. Journal of Anthropological Research 37: 387-401.

Brosius, Christiane. 2010. India's Middle Class: New Forms of Urban Leisure, Consumption and Prosperity. London: Routledge.

Brosius, Christiane and Melissa Butcher, eds. 1999. Image Journeys: Audio-Visual Media and Cultural Change in India. New Delhi: Sage.

Chabria, Suresh. 1994. Before Our Eyes: A Short History of India's Silent Cinema. In Light of Asia: Indian Silent Film (1912-1934), edited by Suresh Chabria, 3-24. Pordenone/Pune: National Film Archive of India.

Dasgupta, Chidananda. 1991. The Painted Face. New Delhi: Roli Books.

Dasgupta, Surendranath N. 1960. Fundamentals of Indian Art. Bombay: Bharatiya Vidya Bhavan.

Derne, Steve. 2008. Globalization on the Ground: Media and the Globalization of Culture, Class and Gender in India. New Delhi: Sage.

Deshpande, Anirudh. 2009. Images and Power in Modern Visual Narratives. In Class, Power and Consciousness in Indian Cinema and Television, 1-50. New Delhi: Primus Books.

Dudrah, Rajinder. 2012. Bollywood Travels: Culture, Diaspora and Border Crossings in Popular Hindi Cinema. London: Routledge.

Dutta, Medha. 2013. From Beach to Desert: Dream Weddings are Just a Click Away. The Times of India, September 2, 11.

Dwyer, Rachel. 2006. Filming the Gods: Religion and Indian Cinema. London: Routledge.

Dwyer, Rachel and Divia Patel. 2002. Cinema India: The Visual Culture of the Hindi Film. New Delhi: Oxford University Press.

Dwyer, Rachel and Jerry Pinto. 2011. Beyond the Boundaries of Bollywood Cinema: The Many Forms of Hindi Cinema. New Delhi: Oxford University Press.

Eck, Diana L. 1998. Darśan: Seeing the Divine Image in India. New York: Columbia University.

Fernandes, Leela. 2000. Nationalizing the Global: Media Images, Cultural Politics, and the Middle Class in India. Media, Culture and Society 22 (5): 611-628.

Gehlawat, Ajay. 2010. Reframing Bollywood: Theories of Popular Hindi Cinema. New Delhi: Sage Publications.

Kohli-Khandekar, Vanita. 2013. The Myth of the Overseas Market. Business Standard (Ahmedabad Edition), September 20, 1911.

Kumar, Keval J. 2010. Mass Communication in India, 4th ed. Bombay: Jaico Books.

Kumar, Keval J., ed. 2011. India's Many Cinemas: Theoretical Perspectives. Journal of Creative Communications 6 (1-2).

Lutgendorf, Philip. 1997. All in the (Raghu) Family: A Video Epic in Cultural Context. In Media and the Transformation of Religion in South Asia, edited by Lawrence A. Babb and Susan S. Wadley. New Delhi: Motilala Banarsidas.

Prasad, Madhava. 1998. Ideology of the Hindi Film: A Historical Construction. New York: Oxford University Press.

Rajadhyaksha, Ashish. 2004. The "Bollywoodization" of the Indian Cinema: Cultural Nationalism in a Global Arena. In City Flicks, edited by Preben Kaarsholm, 113-139. Calcutta: Seagull.

Thussu, Daya K. 2011. News as Entertainment: The Rise of Global Infotainment. London: Sage.

Thussu, Daya. K. 2013. Foreword. In Bollywood and Globalization, edited by David Schaefer and Kavita Karan, xvi-xvii. London: Routledge.

Uhl, Matthias and Keval J. Kumar. 2004. Indischer Film: Eine Einführung. Bielefeld: Transcript.

Uppal, Charu. 2011. Dispensing Nostalgia for a Price: Bollywood in the Lives of Indo-Fijians. Journal of Creative Communications 6 (1-2): 103-122. 
Vasudevan, Ravi. 2011. The Many Meanings of "Bollywood". In Beyond the Boundaries of Bollywood: The Many Forms of Hindi Cinema, edited by Rachel Dwyer and Jerry Pinto. 3-29. New Delhi: Oxford University Press.

Vidal, Denis P. 2006. Darshan. Paris: French Institute of Research for Development.

\section{About the Author}

Keval J. Kumar

is an Adjunct Professor at Mudra Institute of Communications, Ahmedabad (India). He was Reader in Communication and Journalism at Pune University (1990-2003) and Director, Symbiosis Institute of Mass Communication (2003-05). He has been Visiting Faculty at Ohio State University, Siegen University, Jacobs University Bremen and Bahrain Training Institute. He is the author of Mass Communication in India (2013. $4^{\text {th }}$ Ed.) and co-author of Environmentalism and the Mass Media: The NorthSouth Divide (2003). 